\title{
Anti-tumor effect by inhibition of NF-kB activation using nafamostat mesilate for pancreatic cancer in a mouse model
}

\author{
KENEI FURUKAWA ${ }^{1,2}$, TOMONORI IIDA ${ }^{1,2}$, HIROAKI SHIBA ${ }^{1,2}$, YUKI FUJIWARA ${ }^{1,2}$, TADASHI UWAGAWA ${ }^{1}$, \\ YOHTA SHIMADA ${ }^{2}$, TAKEYUKI MISAWA ${ }^{1}$, TOYA OHASHI ${ }^{2}$ and KATSUHIKO YANAGA ${ }^{1}$ \\ Departments of ${ }^{1}$ Surgery, and ${ }^{2}$ Gene Therapy, Institute of DNA Medicine, \\ Jikei University School of Medicine, 3-25-8, Nishi-Shinbashi, Minato-ku, Tokyo 105-846, Japan
}

Received June 7, 2010; Accepted July 16, 2010

DOI: $10.3892 /$ or_00000928

\begin{abstract}
Constitutive NF- $\mathrm{kB}$ activation plays a key role in the aggressive behavior of pancreatic cancer. We have reported that nafamostat mesilate, a serine-protease inhibitor, inhibited NF- $\mathrm{KB}$ activation and induced apoptosis in human pancreatic cancer cells. The aim of this study is to evaluate the therapeutic efficacy of nafamostat mesilate against pancreatic cancer. In vitro, nafamostat mesilate inhibited NF-кB activation of human pancreatic cancer cell line (Panc-1) by suppressing Iк $\mathrm{B} \alpha$ phosphorylation and induced caspase- 8 mediated apoptosis. In vivo, Panc-1 was implanted into the back of nude mice. Five weeks after implantation, nafamostat mesilate was injected intraperitoneally as the treatment group $(n=11)$ three times a week for six weeks, while the control group $(n=13)$ received vehicle only. At the end of six-week treatment, the tumors grew up to $12.89 \pm 4.27 \mathrm{~mm}$ (mean $\pm \mathrm{SD}$ ) in the treatment group, and $17.93 \pm 4.45 \mathrm{~mm}$ in the control group, respectively. The tumor volume and weight of the treatment group were reduced by 43 and $61 \%$ as compared with the control group. The tumor growth was significantly inhibited in the treatment group $(\mathrm{p}<0.0001)$. Assays of primary tumors also indicated that nafamostat mesilate

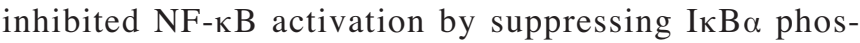
phorylation, resulting in caspase- 8 mediated apoptosis. These results suggested that nafamostat mesilate has anti-neoplastic property against experimental pancreatic cancer.
\end{abstract}

\section{Introduction}

Pancreatic cancer is one of the most fatal human digestive cancers with an overall 5-year survival rate of only $1-4 \%$, because of rapid tumor growth and high potential for distant metastasis. In addition, despite developments in diagnostic

Correspondence to: Dr Kenei Furukawa, Jikei University School of Medicine, 3-25-8, Nishi-Shinbashi, Minato-ku, Tokyo 105-8461, Japan

E-mail: k-furukawa@jikei.ac.jp

Key words: NF-кB inhibitor, nafamostat mesilate, pancreatic cancer techniques and modalities, the majority of patients with pancreatic cancer are diagnosed at the advanced stage. Therefore, only $14 \%$ of patients are amenable to resection (1). Gemcitabine is currently the standard treatment for unresectable pancreatic cancer (2), but the therapeutic benefit of gemcitabine is limited (3). Besides, many patients can not receive sufficient amount of chemotherapy, because of rapid progression, deterioration of general condition, and significant adverse effects. Therefore, new therapeutic approaches, with minimal adverse effects and tolerance even in patients with poor general condition due to advanced cancer, should be developed to further improve the outcome of unresectable pancreatic cancer.

Recent studies have demonstrated that NF- $\kappa \mathrm{B}$ plays an important role in the regulation of cell apoptosis, inflammation, and oncogenesis (4-7). Inhibition of NF- $\mathrm{BB}$ is considered as one of new treatment strategies for cancer patients (8-11). In addition, constitutive activation of NF-kB has been reported to play a key role in the aggressive behavior of pancreatic cancer (12-15). We have reported that nafamostat mesilate inhibits $\mathrm{NF}-\kappa \mathrm{B}$ activation by suppressing I $\mathrm{I} B \alpha$ phosphorylation and induces caspase- 8 mediated apoptosis of pancreatic cancer cells (16). Also, high efficacy of nafamostat mesilate combined with gemcitabine for pancreatic cancer has been demonstrated in animal experiments (17) that applied to clinical trials (18). Nafamostat mesilate, which is a serine-protease inhibitor $(19,20)$, is widely used for treatment of pancreatitis $(21)$, disseminated intravascular coagulation (22), and anticoagulation in hemodialysis (23) in Japan, and has only minimal adverse effects such as hyperkalemia or hyponatremia (24-26).

To evaluate the potential of nafamostat mesilate for possible clinical application to treat unresectable pancreatic cancer, especially for patients in poor status, we explored antitumor and adverse effect of nafamostat mesilate in an experimental pancreatic cancer model.

\section{Materials and methods}

Reagents. Nafamostat mesilate was a kind gift from Torii Pharmaceutical Co., Ltd., (Tokyo, Japan), was dissolved to sterile distilled water $(5 \mathrm{mg} / \mathrm{ml})$ and stored at $-20^{\circ} \mathrm{C}$ until use. 
Cell line. Panc-1, a human pancreatic cancer cell line, was purchased from the American Type Culture Collection and cultured in Dulbecco's modified Eagle's medium (DMEM) containing $10 \%$ fetal bovine serum (Gibco-BRL, NY, USA) and penicillin/streptomycin (Gibco-BRL). The cells were cultured at $37^{\circ} \mathrm{C}$ with $5 \% \mathrm{CO}_{2}$.

Quantitative analysis of $N F-\kappa B$ activity. NF- $\mathrm{BB}$ is typically a heterodimer that consists of the p65 (RelA) and p50 proteins. In an inactive form of NF- $\mathrm{B}$ proteins are sequestered in the cytoplasm with $\mathrm{I} \kappa \mathrm{B}_{\alpha}$. Following I $\mathrm{B} \alpha$ phosphorylation, $\mathrm{NF}-\kappa \mathrm{B}$ proteins are released and translocated into the nucleus, where they activate transcription of target genes. For assessment of the NF- $\mathrm{KB}$ activity in Panc-1 cells treated with nafamostat mesilate, concentration of NF- $\mathrm{KB}$ p65 in the nuclear extracts was measured both in vitro and in vivo. Nucleic extracts of both nafamostat mesilate-treated and control Panc-1 cells were prepared using a nuclear extract kit (Active Motif, Carlsbad, CA, USA) according to the manufacturer's protocol. For in vitro experiment, Panc-1 cells were incubated with nafamostat mesilate $(320 \mu \mathrm{g} / \mathrm{ml})$ as treatment group, or with distilled water as control group for $3 \mathrm{~h}$. The nuclear extracts from both in vitro and in vivo experiments were assayed using an enzyme-linked immunosorbent assay (ELISA) kit (Trans AM ${ }^{\mathrm{TM}} \mathrm{NF}-\kappa \mathrm{B}$; Active Motif) to detect and quantify the NF- $\kappa \mathrm{B}$ activity according to the manufacturer's instructions. Briefly, $10 \mu \mathrm{g}$ of nuclear extract protein was incubated for $1 \mathrm{~h}$ at $25^{\circ} \mathrm{C}$ in microwell coated with an oligonucleotide containing an $\mathrm{NF}-\kappa \mathrm{B}$ p65-binding consensus sequence. Next, the nuclear extract protein was incubated with rabbit anti-NF- $\mathrm{BB}$ p65 antibodies (1:1000 dilution) for $1 \mathrm{~h}$ at $25^{\circ} \mathrm{C}$, followed by incubation with peroxidase-conjugated goat anti-rabbit IgG (1:1000 dilution) for $1 \mathrm{~h}$ at $25^{\circ} \mathrm{C}$. The peroxidase activity was visualized by the tetramethylbenzidine reaction, and the optimal density was measured at $450 \mathrm{~nm}$.

Western blot analysis. To evaluate the inhibitory effect of nafamostat mesilate on NF-кB signaling due to suppression of I $\mathrm{KB} \alpha$ phosphorylation, and apoptotic effect for Panc-1 cells in vitro and in vivo, Iк $\mathrm{B} \alpha$, phosphorylated $\mathrm{I} \kappa \mathrm{B} \alpha$, procaspase- 8 , and cleaved caspase- 8 protein level in whole cell extracts of Panc-1 cells treated with nafamostat mesilate were determined by Western blot analysis. Protease inhibitor cocktail and phosphatase inhibitor cocktail tablets were purchased from Roche Diagnostics (Indianapolis, IN, USA). Pro- and cleaved caspase- 8 , IкB $\alpha$, phosphorylated ІкB $\alpha$ monoclonal antibodies were purchased from Cell Signaling Technology (Beverly, MA, USA). For in vitro experiment, Panc-1 cells were incubated with nafamostat mesilate (320 $\mu \mathrm{g} / \mathrm{ml})$ as the treatment group, or with distilled water as control group for 3 or $24 \mathrm{~h}$. Protein samples of nafamostat mesilate treated and control Panc-1 cells for SDS-PAGE were prepared according to the procedure previously described (27). These samples from both in vitro and in vivo experiments were resolved by SDS-PAGE on 4-20\% acrylamide gradient gels using Tris-glycine buffer and transferred onto a nitrocellulose membrane. The blotted membranes were blocked with incubation in Tris-buffered saline (TBS) containing $0.1 \%$ casein, and $0.05 \%$ Tween $-20^{\circledR}$ (MP Bio- medicals, Solon, OH, USA ) at room temperature for $2 \mathrm{~h}$. Immunostaining was performed by incubating the blots in each primary antibody at appropriate dilution overnight. After brief washing, the membranes were incubated with the alkaline-phosphatase-labeled secondary antibody (Histofine, Nichirei, Tokyo, Japan) for $2 \mathrm{~h}$ and developed by using nitro blue tetrazolium/5-Bromo-4-chloro-3-indolyl phosphate (NBT/BCIP) reagent (Bio-Rad, Hercules, CA, USA).

Cell proliferation assay. For evaluating the anti-tumor effect of nafamostat mesilate, the cell proliferation of Panc-1 cells after nafamostat mesilate treatment was measured. Panc-1 cells $\left(1 \times 10^{4}\right)$ seeded into a 96 -well plate were incubated with nafamostat mesilate $(320 \mu \mathrm{g} / \mathrm{ml})$ as treatment group, or with distilled water as control group for 24,48 or $72 \mathrm{~h}$. The cell proliferation was measured with Progma celltiter 96 Aquenous One Solution Cell Proliferation Assay (Progma, Madison, WI, USA) following the manufacturer's instructions.

Cell cycle analysis. For evaluating the induction of apoptosis by nafamostat mesilate, cell cycle analysis was performed. Panc-1 cells were incubated with nafamostat mesilate $(320 \mu \mathrm{g} / \mathrm{ml})$ as treatment group, or with distilled water as control group for $24 \mathrm{~h}$. The cell cycle was analyzed by flow cytometry. In brief, the cells were harvested and $1 \times 10^{6}$ were fixed with $70 \%(\mathrm{v} / \mathrm{v})$ ethanol stored at $-20^{\circ} \mathrm{C}$ until use. After centrifugation, the cell pellet was washed with phosphatebuffer saline (PBS). The cells were resuspended in PBS containing propidium iodode $(50 \mu \mathrm{g} / \mathrm{ml})$ and incubated at room temperature for $10 \mathrm{~min}$, followed by incubation with $0.1 \%$ Triton ${ }^{\circledR}$ X-100 (MP Biomedicals) for $10 \mathrm{~min}$. The cells were incubated with $0.1 \%$ sodium citrate and DNase-free RNase $(1 \mu \mathrm{g} / \mathrm{ml})$ for $10 \mathrm{~min}$. DNA content was determined with a FACScan flow cytometer (Becton-Dickinson, Franklin Lakes, NJ, USA).

Animals and xenograft pancreatic cancer model. Five-week old male nude mice (BALBc nu/nu), were purchased from CLEA Japan Incorporated (Tokyo, Japan). The animals were housed under specific pathogen-free conditions in a biological cabinet at the Laboratory Animal Facility of Jikei University School of Medicine. The animals were maintained with a 12-h light-dark cycle at a temperature of $22 \pm 2^{\circ} \mathrm{C}$ and $55 \pm 5 \%$ humidity in a room with a filtered air supply.

A mouse pancreatic cancer model was established by

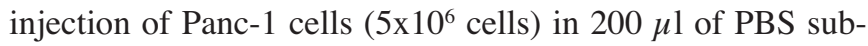
cutaneously into the right side of the back of the animals. At five weeks after implantation, the animals were randomized into the following two groups; treatment group $(n=11)$, intraperitoneally injected nafamostat mesilate $(30 \mu \mathrm{g} / \mathrm{g})$ three times a week for six weeks, and control group $(n=13)$, intraperitoneal injection of the equal amount of vehicle three times a week for six weeks. The diameters of tumors in both groups were measured on the day of nafamostat mesilate or vehicle injection. At the end of the treatments, blood samples were taken, and animals were sacrificed. Subcutaneous tumors were excised, and the volume and weight were measured. Thereafter, paraformaldehyde-fixed and paraffin-embedded for immunohistochemistry and TdTmediated dUTP-X nick end labeling (TUNEL) assay. 
Nucleic and whole protein were extracted from the tumor tissue for ELISA and Western blot analysis for assessment of inhibitory effect for $\mathrm{NF}-\kappa \mathrm{B}$ activity and apoptotic effect for cancer cells by nafamostat mesilate treatment. These in vivo experimental protocols were approved by the animal committee of Jikei University School of Medicine.

Histological studies. Paraffin sections of tumor tissue were stained immunohistochemically using NF-кB p65 monoclonal antibody (Epitomics, Burlingame, CA, USA, 1:500) as a primary antibody and Dako Envision Kit/HRP as a secondary antibody (Dako, Carpinteria, CA, USA) for evaluating NF-кB activation. TUNEL assay with In Situ Cell Death Detection Kit, TMR red (Roche Diagnostics, Indianapolis, IN, USA) was performed for evaluating induction of apoptosis. These assessments followed the manufacturer's instructions.

Blood samples analysis. The major adverse effects of nafamostat mesilate consist of hyperkalemia, hyponatremia and hepatopathy. To evaluate adverse effects, serum potassium, sodium, and alanine aminotransferase levels were measured.

Statistical analysis. Non-paired t-test and repeated measures ANOVA were used for statistical studies. All p-values were considered statistically significant when the associated probability was $<0.05$.

\section{Results}

Inhibition of $N F-\kappa B$ activity by nafamostat mesilate in vitro. In assessment of the NF- $\mathrm{KB}$ activity using ELISA, concentration of NF- $\mathrm{B}$ p65 in the nuclear extracts of Panc-1 cells treated with nafamostat mesilate was significantly lower than those in control group ( $p=0.0001$, Fig. 1a). In Western blot analysis, concentration of phosphorylated $\mathrm{I} \kappa \mathrm{B} \alpha$ was lower, and concentration of $\mathrm{I} \kappa \mathrm{B} \alpha$ was higher in Panc-1 cells treated with nafamostat mesilate, in comparison with those in control group (Fig. 1b). These results showed that NF-кB activity was inhibited due to suppressed I $\mathrm{K} \mathrm{B} \alpha$ phosphorylation in Panc-1 cells treated with nafamostat mesilate.

Inhibition of cell proliferation by nafamostat mesilate in vitro. In the cell proliferation assay, cell viability of Panc-1 cells treated with nafamostat mesilate was significantly lower than those in control group at each exposure time, including 24,48 and $72 \mathrm{~h}\left(75.58 \pm 7.96 \%,{ }^{*} \mathrm{p}=0.0030\right.$, $56.47 \pm 4.97 \%,{ }^{* *} \mathrm{p}<0.0001,40.95 \pm 5.85 \%,{ }^{* * *} \mathrm{p}<0.0001$, Fig. 2). In addition, cell viability of Panc-1 cells treated with nafamostat mesilate was decreased exposure timedependently $(\mathrm{p}<0.0001)$.

Induction of apoptosis by nafamostat mesilate in vitro. In FACS analysis, cell counts of M1 period in nafamostat mesilate-treated cells were greater than those in control cells (Fig. 3a). In Western blot analysis, concentration of pro-caspase- 8 was lower, and concentration of cleaved caspase- 8 was higher in nafamostat mesilate-treated cells, a

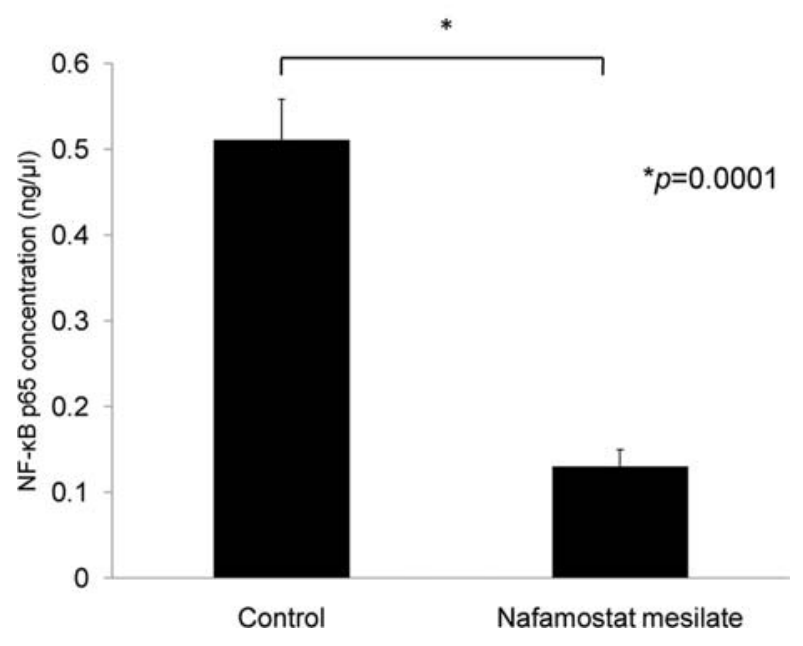

b

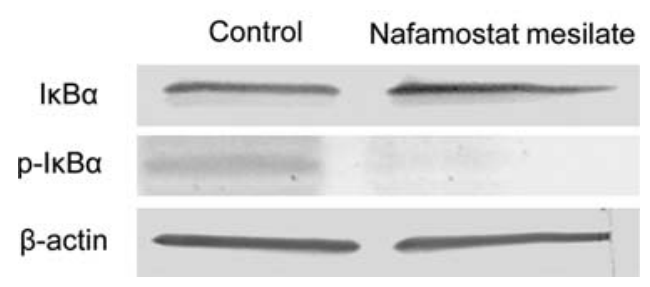

Figure 1. (a) Concentration of NF-кB p65 in the nuclear extracts of Panc-1 cells treated with nafamostat mesilate was significantly lower than those in control group. (b) In Western blot analysis, concentration of phosphorylated $\mathrm{I} \kappa \mathrm{B} \alpha$ was lower, and concentration of $\mathrm{I} \kappa \mathrm{B} \alpha$ was higher in Panc- 1 cells treated with nafamostat mesilate, in comparison with those in control group.

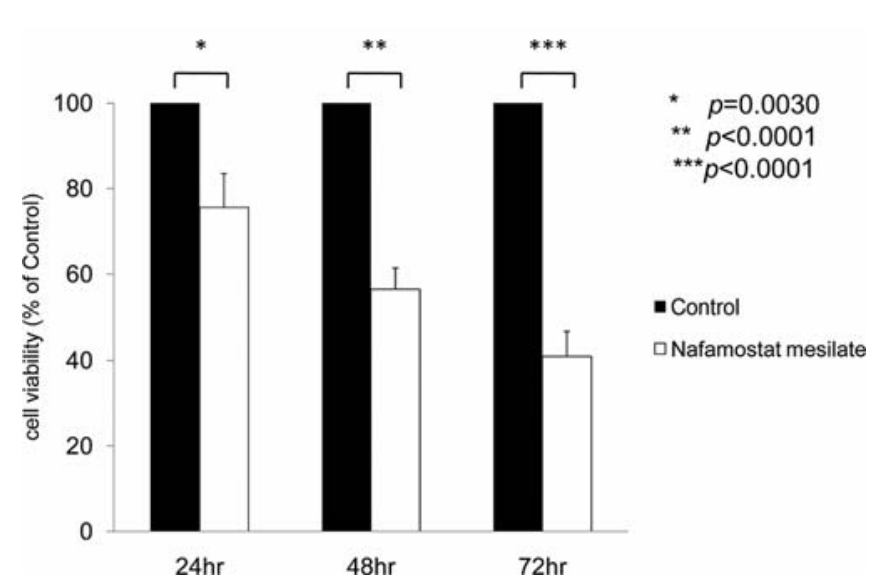

Figure 2. Cell viability of Panc-1 cells treated with nafamostat mesilate was significantly lower than those in control group at each exposure time, including 24,48 and $72 \mathrm{~h}$.

in comparison with those in control cells (Fig. 3b). The results showed that nafamostat mesilate induced caspase- 8 mediated apoptosis of Panc-1 cells, and increased the sub-G1 cell population.

Anti-tumor effect of in vivo nafamostat mesilate treatment. Fig. 4a shows tumors in both control and nafamostat mesilate-treated tumors at the end of study, respectively. As to 
a

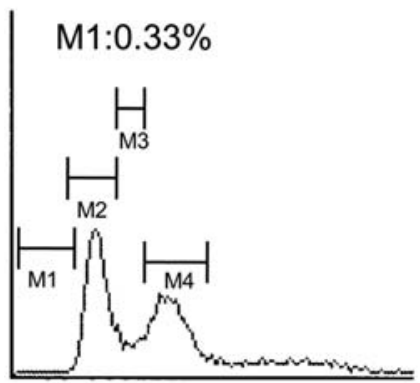

Control

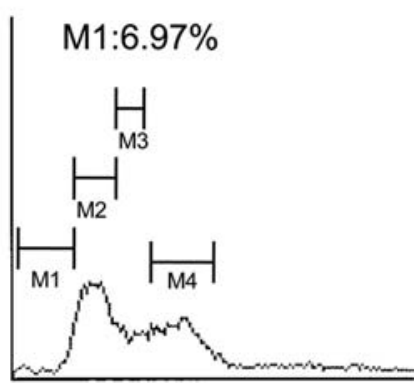

Nafamostat mesilate b

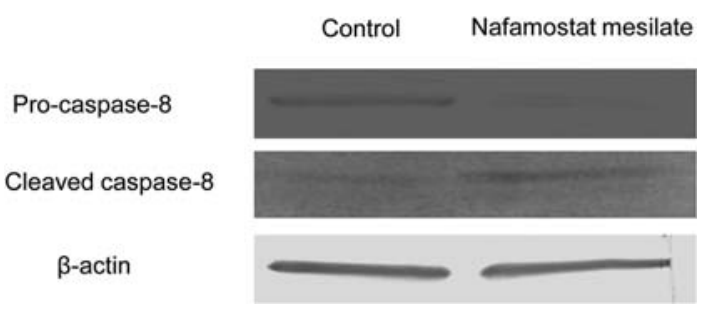

Figure 3. (a) Cell count of M1 period in nafamostat mesilate treatment cells was greater than those in control cells in FACS analysis. (b) Concentration of pro-caspase- 8 was lower, and concentration of cleaved caspase- 8 was higher in nafamostat mesilate-treated cells, in comparison with those in control cells in Western blot analysis.

a

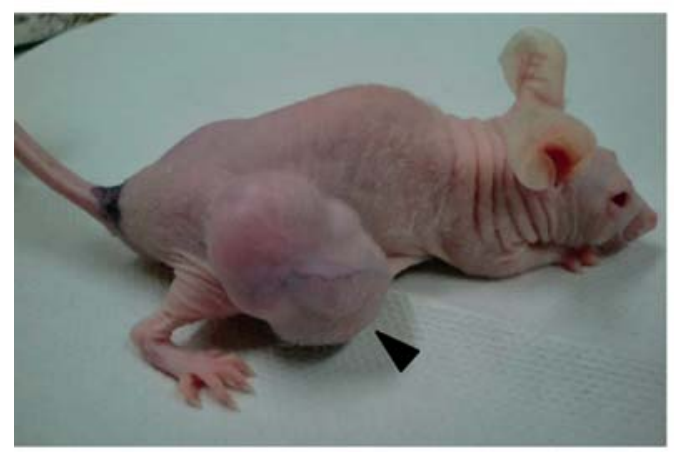

Control

b

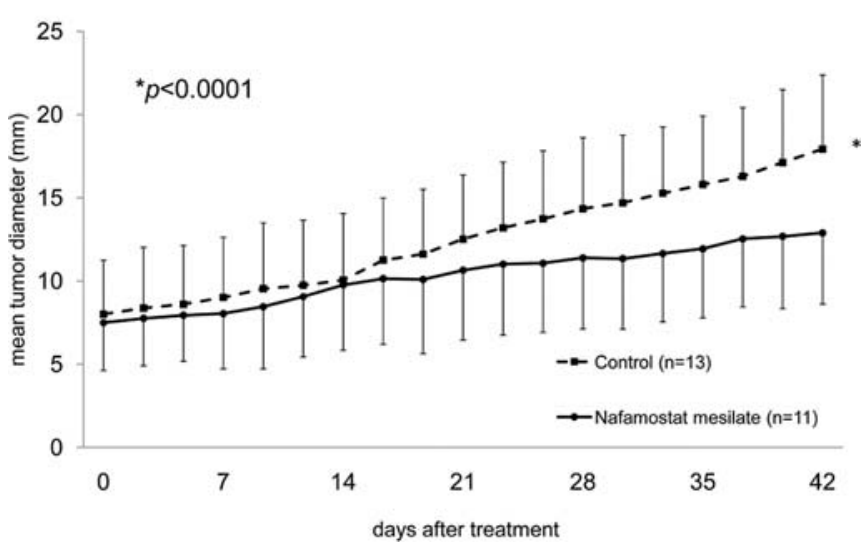

d

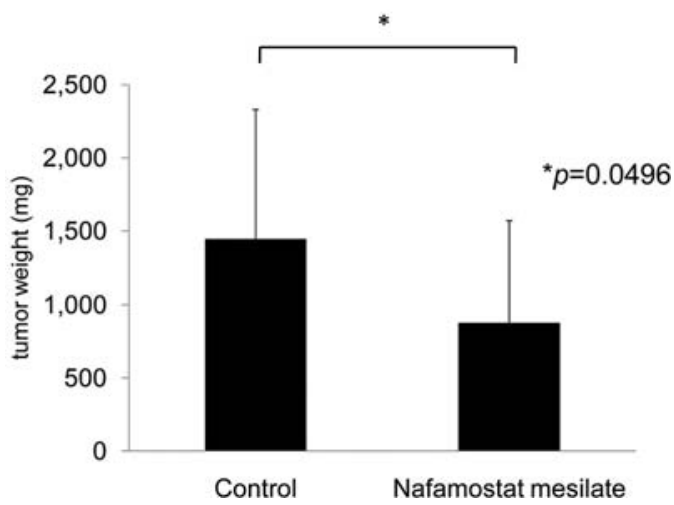

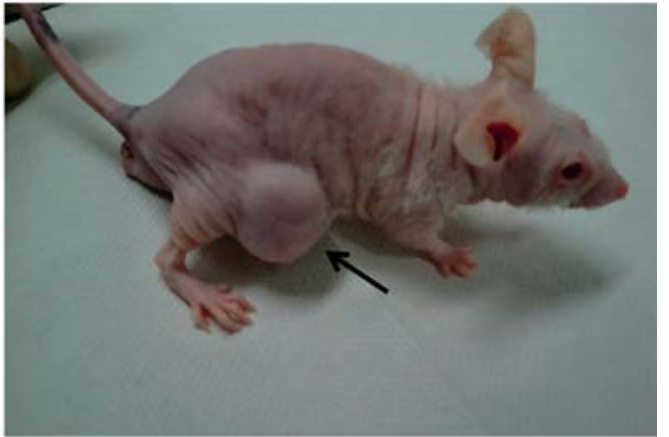

Nafamostat mesilate

C

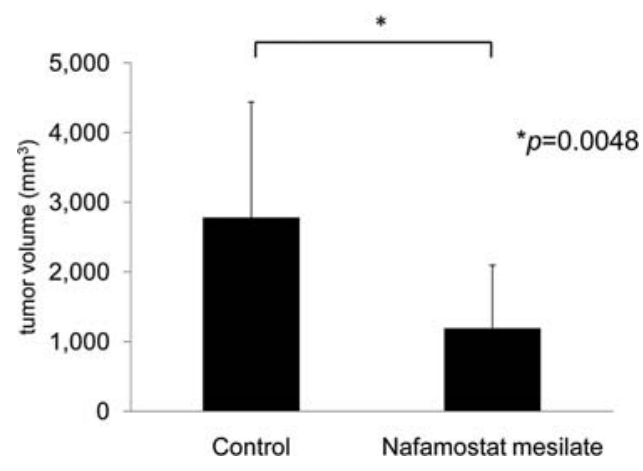

Figure 4. (a) At the end of the study, nafamostat mesilate-treated tumors (arrow) were larger than control tumors (arrowhead). (b) The tumor growth in nafamostat mesilate-treated group was significant smaller than those in the control group. (c) The tumor volumes in nafamostat mesilate-treated group were significantly fewer than those in the control group. (d) The tumor weights in nafamostat mesilate-treated group were significantly fewer than those in control group.

changes in the tumor diameter, the initial diameter at five weeks after implantation in control group was $8.01 \pm 3.24 \mathrm{~mm}$, which gradually grew to $17.93 \pm 4.45 \mathrm{~mm}$ at the end of six 
a

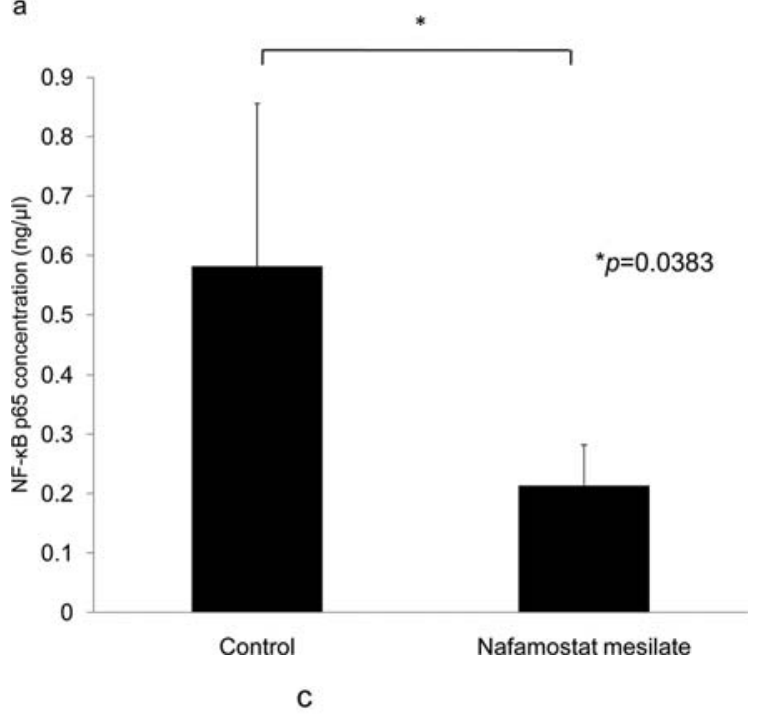

b

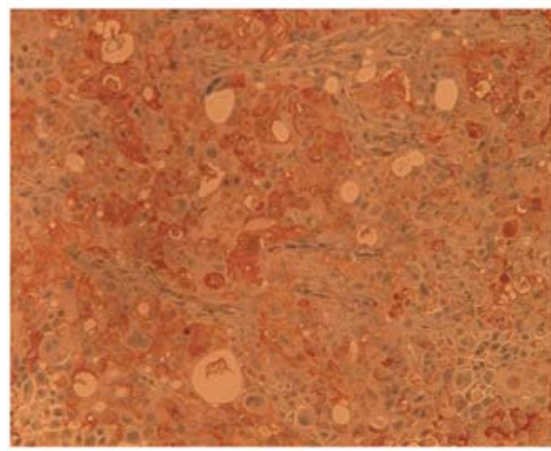

Control

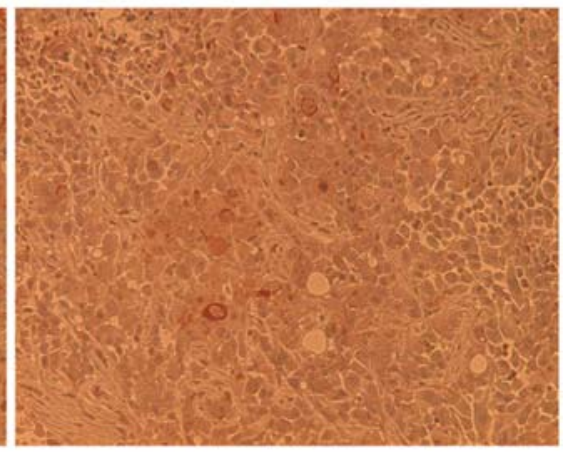

Nafamostat mesilate

Figure 5. (a) Concentration of NF-кB p65 measured by ELISA in the nuclear extracts of nafamostat mesilate-treated tumor was significantly lower than those in control. (b) Concentration of phosphorylated IкB $\alpha$ was lower, and concentration of IкB $\alpha$ was higher in nafamostat mesilate-treated tumors, in comparison with those in control in Western blot analysis. (c) In immunohistochemical staining, reduced nuclear translocation of $\mathrm{NF}-\mathrm{\kappa} B$ p65 was shown in nafamostat mesilate-treated tumors, in comparison with control tumors $(\mathrm{x} 200)$.

weeks. In contrast, the tumor diameter in nafamostat mesilate treatment group was $7.5 \pm 2.88 \mathrm{~mm}$, which gradually grew to $12.89 \pm 4.27 \mathrm{~mm}$, but significant slower than those of the control group $(\mathrm{p}<0.0001)$ (Fig. 4b). Resected tumor volumes and weights in control group were 2.779.5 $1.658 .48 \mathrm{~mm}^{3}$ and $1.445 .23 \pm 885.43 \mathrm{mg}$, respectively. In contrast, those in the treatment group were 1.190.78 $903.49 \mathrm{~mm}^{3}$ and $878.64 \pm 692.17 \mathrm{mg}$. Both tumor volumes and weights in treatment group were significantly smaller than those of control group ( $p=0.0048$, Fig. $4 c, p=0.0496$, Fig. 4d). These data showed that nafamostat mesilate treatment had inhibitory effect on the tumor growth of pancreatic cancer in an experimental mouse model.

Inhibition of $N F-\kappa B$ activity by nafamostat mesilate in vivo. In assessment of the NF- $\mathrm{KB}$ activity using ELISA, concentration of $\mathrm{NF}-\kappa \mathrm{B}$ p65 in the nuclear extracts of nafamostat mesilate-treated tumor was significantly lower than those in control ( $p=0.0383$, Fig. 5a). In Western blot analysis, concentration of phosphorylated IкB $\alpha$ was lower, and concentration of $\mathrm{I} \kappa \mathrm{B} \alpha$ was higher in nafamostat mesilatetreated tumors, in comparison with those in control (Fig. 5b). In immunohitochemical staining, reduced nuclear trans- location of NF-кB p65 was shown in nafamostat mesilatetreated tumors (Fig. 5c). These results showed that NF-кB activity was inhibited due to suppressed IкB $\alpha$ phosphorylation in nafamostat mesilate-treated tumors in vivo, which is in accordance with the results of the in vitro experiment.

Induction of apoptosis by nafamostat mesilate in vivo. In Western blot analysis, concentration of pro-caspase- 8 was lower, and concentration of cleaved caspase- 8 was higher in nafamostat mesilate-treated tumors, in comparison with those in control (Fig. 6a). In TUNEL staining, TUNEL-positive cells were greater in nafamostat mesilate-treated tumors (Fig. 6b). These results showed that nafamostat mesilate treatment induced a caspase- 8 mediated apoptosis in vivo, which is in accordance with the results of the in vitro experiment.

Adverse effects of in vivo nafamostat mesilate treatment. In post-therapeutic blood sample results, serum potassium levels of nafamostat mesilate-treated and control group were $5.07 \pm 0.67 \mathrm{mmol} / 1$ and $4.6 \pm 0.16 \mathrm{mmol} / 1$, respectively $(\mathrm{p}=0.1160)$. Serum sodium levels of treatment and control 
a

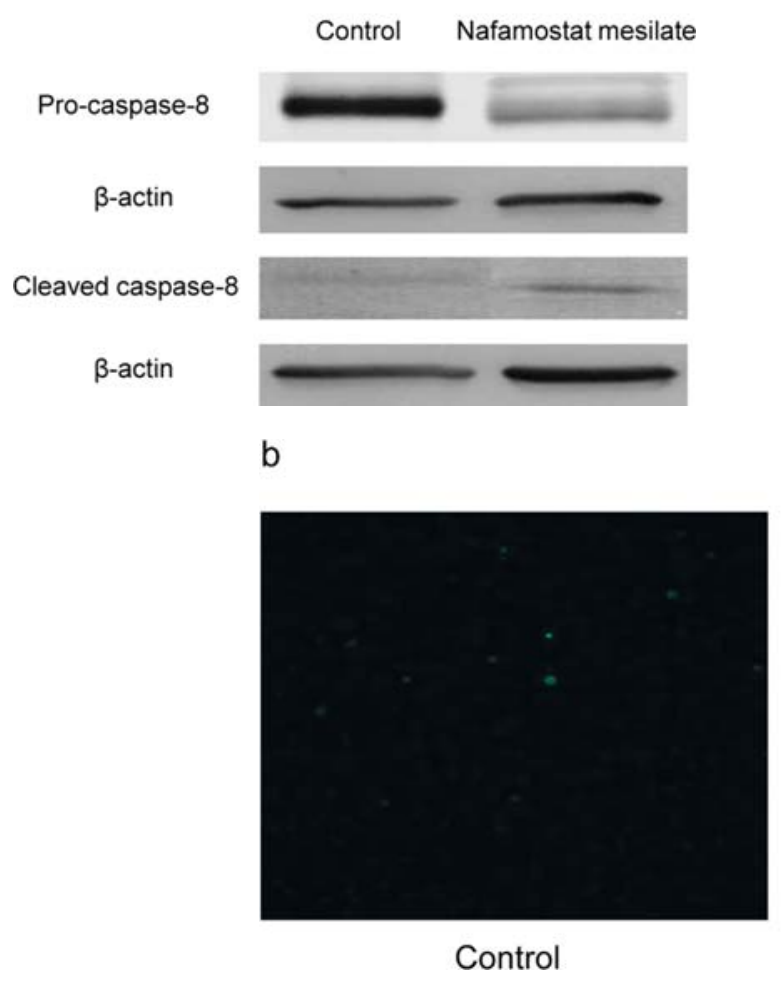

group were $152 \pm 1.73 \mathrm{mmol} / \mathrm{l}$ and $152 \pm 2.45 \mathrm{mmol} / \mathrm{l}$, respectively $(\mathrm{p}=1.0000)$. Serum alanine aminotransferase levels of treatment and control group were $36 \pm 7.69 \mathrm{IU} / 1$ and $43.75 \pm 13.72 \mathrm{IU} / 1$, respectively $(\mathrm{p}=0.2380)$. Blood test results related to known nafamostat mesilate adverse effects, such as hyperkalemia, hyponatremia and hepatopathy, were comparable between the two groups.

\section{Discussion}

$\mathrm{NF}-\kappa \mathrm{B}$ regulates the expression of genes involved in inflammatory cytokines, adhesion molecules and anti-apoptotic proteins. Therefore, the $\mathrm{NF}-\kappa \mathrm{B}$ inhibitor may suppress proliferation, invasion, metastasis and chemoresistance in tumors. Several reports described anti-tumor effect of protease inhibitor as an $\mathrm{NF}-\kappa \mathrm{B}$ inhibitor. Tsuzuki et al and Chih et al reported that nafamostat mesilate inhibited $\mathrm{NF}-\kappa \mathrm{B}$ activation in inflammation $(28,29)$. Kimura et al reported that nafamostat mesilate inhibited liver metastasis and invasion of colon cancer cells in a mouse model (30), and Outa et al reported that nafamostat mesilate inhibited growth and invasion of pancreatic cancer cells by blocking tumor-associated trypsinogen into protease-activated receptor-2 in vitro $(31,32)$. Uchima et al reported gabexate mesilate, a kind of protease inhibitors, prevented the invasive potential of pancreatic cancer cells and liver metastasis in nude mice (33). Yoon et al reported gabexate mesilate reduced the invasion and metastasis of colon cancer cells by inhibiting matrix metalloproteinases in vitro and in vivo (34).

Several drugs, which play roles as NF- $\kappa \mathrm{B}$ inhibitors, have also been used for treatment of malignancies. However, these drugs have problems in clinical application, including
Figure 6. (a) In Western blot analysis, concentration of pro-caspase- 8 was lower, and concentration of cleaved caspase- 8 was higher in nafamostat mesilate-treated tumors, in comparison with those in control. (b) In TUNEL staining, TUNEL-positive cells were greater in nafamostat mesilate-treated tumors, in comparison with control (x100).

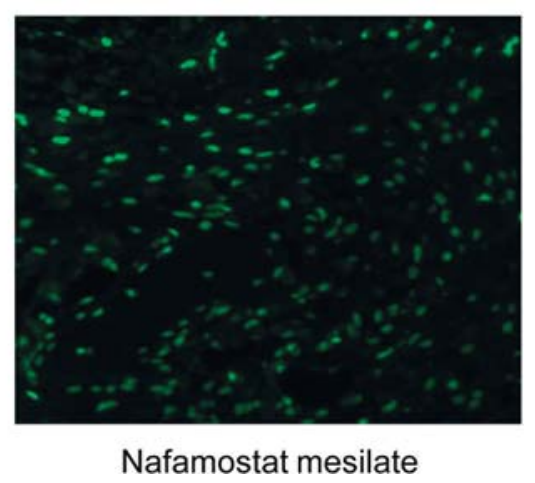

adverse effects. Bortezomib, which inhibits proteasome resulting in inhibition of $\mathrm{NF}-\kappa \mathrm{B}$, is used for refractory and relapsed multiple myeloma in clinical medicine (35), but also inhibits reduction of unnecessary ubiquitin proteins. Curcumin, which is a yellow pigment present in the rhizome of turmeric has been shown to suppress NF- $\mathrm{KB}$ activation (36), and a phase II trial of curumin for advanced pancreatic cancer has been reported (37). However, curcumin is reported to impair function of tumor suppressor p53 in colon cancer cells (38). Resveratrol, a component of grapes, berries and peanuts, has been demonstrated to be a potent blocker of the NF-кB pathway (39) that enhances antitumor activity of gemcitabine in orthotopic mouse model of human pancreatic cancer (40). In the viewpoint of drug administration, resveratrol is available only orally, and has strong action for tumors in direct contact with the drug, such as skin and gastrointestinal tract tumors (41). Recent therapeutic advances in chemotherapy for malignancy allow patients with advanced cancer to live longer than before. Consequently, developments of therapeutic approach with less invasiveness and adverse effects for patients with poor general condition due to advanced cancer are needed to maintain and improve quality of life. Nafamostat mesilate is widely used for patients with poor performance status and organ function due to pancreatitis, disseminated intravascular coagulation or chronic renal failure, with minimal adverse effects. Therefore, nafamostat mesilate has a potential to become a new therapeutic option for cancer patients. In addition, because nafamostat mesilate is administrated via infusion, serum drug concentration is not affected by alimentary absorption.

In conclusion, we demonstrated anti-tumor effect of nafamostat mesilate via inhibition of $\mathrm{NF}-\mathrm{\kappa B}$ activation by 
suppression of IкB $\alpha$ phosphorylation, and induction caspase- 8 mediated apoptosis in vitro and in vivo without definite adverse effects. Nafamostat mesilate treatment may be therapeutic application for patients with advanced pancreatic cancer.

\section{References}

1. Niederhuber JE, Brennan MF and Menck HR: The National Cancer Date Base report on pancreatic cancer. Cancer 76: 1671-1677, 1995.

2. Burris HA, Moore MJ, Andersen J, Green MR, Rothenberg ML, Modiano MR, Cripps MC, Portenoy RK, Storniolo AM, Tarassoff P, Nelson R, Dorr FA, Stephens CD and Von Hoff DD: Improvements in survival and clinical benefit with gemcitabine as first-line therapy for patients with advanced pancreas cancer: a randomized trial. J Clin Oncol 15: 2403-2413, 1997.

3. Berlin JD, Catalano P, Thomas JP, Kugler JW, Haller DG and Benson AB III: Phase III study of gemcitabine in combination with fluorouracil versus gemcitabine alone in patients with advanced pancreatic carcinoma: Eastern Cooperative Oncology Group Trial E2297. J Clin Oncol 20: 3270-3275, 2002.

4. Chen F, Castranova V and Shi X: New insights into the role of nuclear factor- $\mathrm{kB}$ in cell growth regulation. Am J Pathol 159: 387-397, 2001

5. Amer BA and David B: An essential role for NF-кB in preventing TNF-alpha-induced cell death. Science 274: 782-784, 1996

6. Antwerp VDJ, Seamus MJ, Tal K, Douglas GR and Inder VM: Suppression of TNF-alpha-induced apoptosis by NF-кB. Science 274: 787-789, 1996.

7. Karin M and Lin A: NF-кB at the crossroads of life and death. Nat Immunol 3: 221-227, 2002

8. Huang S, Robinson JB, DeGuzman A, Bucana CD and Fiddler IJ: Blockade of nuclear factor- $\mathrm{kB}$ signaling inhibits angiogenesis and tumorigenicity of human ovarian cancer cells by suppressing expression of vascular endothelial growth factor and interleukin 8. Cancer Res 60: 5334-5339, 2000

9. Matsumoto G, Namekawa J, Muta M, Nakamura T, Bando H, Tohyama K, Toi M and Umezawa K: Targeting of nuclear factor $\mathrm{\kappa B}$ pathways by Dehydroxymethyleoxyquinomicin, a novel inhibitor of breast carcinomas: antitumor and antiangiogenic potential in vivo. Clin Cancer Res 11: 1287-1293, 2005 .

10. Kikuchi E, Horiguchi Y, Nakashima J, Kuroda K, Oya M, Ohigashi T, Takahashi N, Shima Y, Umezawa K and Kurai M: Suppression of hormone-refractory prostate cancer by a novel nuclear factor $\mathrm{\kappa B}$ inhibitor in nude mice. Cancer Res 63: 107-110, 2003

11. Huang S, Pettaway CA, Uehara H, Bucana CD and Fidler IJ: Blockade of NF- $\mathrm{kB}$ activity in human prostate cancer cells is associated with suppression of angiogenesis, invasion, and metastasis. Oncogene 20: 4188-4197, 2001.

12. Wang W, Abbruzzese JL, Evans DB, Larry L, Cleary KR and Chiano PJ: The nuclear factor-кB RelA transcription factor is constitutively activated in human pancreatic adenocarcinoma cells. Clin Cancer Res 5: 119-127, 1999.

13. Wang W, Abbruzzese JL, Evans DB and Chiano PJ: Overexpression of urokinase-type plasminogen activator in pancreatic adenocarcinoma is regurated by constitutively activated RelA. Oncogene 18: 4554-4563, 1999.

14. Fujioka S, Sclabas GM, Schmidit C, Niu J, Frederick WA, Dong QG, Abbruzzese JL, Evans DB, Baker C and Chiao PJ:

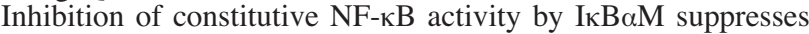
tumorigenesis. Oncogene 22: 1365-1370, 2003.

15. Fujioka S, Sclabas GM, Schmidit C, Frederick WA, Dong QG, Abbruzzese JL, Evans DB, Baker C and Chiano PJ: Function of nuclear $\kappa \mathrm{B}$ in pancreatic cancer metastasis. Clin Cancer Res 9: 346-354, 2003

16. Uwagawa T, Li Z, Chang Zhe, Xia Q, Peng B, Sclabas GM, Ishiyama S, Hung MC, Evans DB, Abbruzzese JL and Chiano PJ: Mechanisms of synthetic serine protease inhibitor (FUT-175)mediated cell death. Cancer 109: 2142-2153, 2007.

17. Uwagawa T, Chiano PJ, Gocyo T, Hirohara S, Misawa T and Yanaga K: Combination chemotherapy of nafamostat mesilate with gemcitabine for pancreatic cancer targeting NF- $\mathrm{\kappa B}$ activation. Anticancer Res 29: 3173-3178, 2009.
18. Uwagawa T, Misawa T, Sakamoto T, Ito R, Gocho T, Shiba H, Wakiyama S, Hirohara S, Sadaoka S and Yanaga K: A phase I study of full-dose gemcitabine and regional arterial infusion of nafamostat mesilate for advanced pancreatic cancer. Ann Oncol 20: 239-243, 2009

19. Fujii S and Hitomi Y: New synthetic inhibitors of C1r, C1 esterase, thrombin, kallikrein and trypsin. Biochim Biophys Acta 661: 342-345, 1981.

20. Aoyama T, Ino Y, Ozeki M, Oda M, Sato T, Koshiyama Y, Suzuki S and Fujita M: Pharmacological studies of FUT175 , nafamstat mesilate. I. Inhibition of protease activity in in vitro and in vivo experiments. Jpn J Pharmacol 35: 207-227, 1984

21. Iwaki M, Ino Y, Motoyoshi A, Ozeki M, Sato T, Kurumi M and Aoyama T: Pharmacological studies of FUT-175, nafamostat mesilate. V. Effects on the pancreatic enzymes and experimental acute pancreatitis in rats. Jpn $\mathrm{J}$ Phamacol 41: 155-162, 1986.

22. Takahashi H, Takizawa S, Tatewaki W, Nagai K, Wada K, Hanano M and Shibata A: Nafamostat mesilate (FUT-175) in the treatment of patients with disseminated intravascular coagulations. Thromb Haemost 62: 372, 1989.

23. Ohtake Y, Hirasawa H, Sugai T, Oda S, Shiga H, Matsuda K and Kitamura N: Nafamostat mesilate as anticoagulant in continuous hemofiltration and continuous hemodiafiltration. Contrib Nephrol 93: 215-217, 1991.

24. Muto S, Imai M and Asano Y: Effect of nafamostat mesilate on $\mathrm{Na}^{+}$and $\mathrm{Na}^{+}$transport properties in the rabbit cortical collecting duct. Br J Pharmacol 109: 673-678, 1993.

25. Muto S, Imai M and Asano Y: Mechanisms of the hyperkalemia caused by nafamostat mesilate: effects of its two metabolites on $\mathrm{Na}^{+}$and $\mathrm{K}^{+}$transport properties in the rabbit cortical collecting duct. Br J Pharmacol 111: 173-178, 1994

26. Kitagawa H, Chang $\mathrm{H}$ and Fujita T: Hyperkalemia due to nafamostat mesylate. N Engl J Med 332: 687, 1995.

27. Shimada Y, Fukuda T, Aoki K, Yukawa T, Iwamuro S, Ohkawa K and Takada K: A protocol for immunoaffinity separation of the accumulated ubiquitin-protein conjugates solubilized with sodium dodecyl sulfate. Anal Biochem 377: 77-82, 2008.

28. Tsuzuki H, Tani T and Hanazawa K: Regulation of NF-кB. Iyakunomonn 43: 162-167, 2003 (in Japanese).

29. Chen CL, Wang SD, Zeng ZY BSc, Lin KJ, Kao ST, Tani T, Yu CK and Wang JY: Serine protease inhibitors nafamostat mesilate and gabexate mesilate atteneuate allergen-induced airway inflammation and eosinophilia in a murine model of asthma. J Allergy Clin Immunol 118: 105-112, 2006.

30. Kimura T, Fuchimoto S, Iwagaki H, Hizuta A and Orita K: Inhibitory effect of nafamoatat mesilate on metastasis into the livers of mice and on invasion of the extracellular matrix by cancer cells. J Int Med Res 20: 343-352, 1992.

31. Ohta T, Shimizu K, Yi S, Takamura H, Amaya K, Kitagawa H, Kayahara M, Ninomiya I, Fushida S, Fujimura T, Nishimura G and Miwa K: Protease-activated receptor-2 expression and the role of trypsin in cell proliferation in human pancreatic cancers. Int J Oncol 23: 61-66, 2003.

32. Tajima H, Ohta T, Elnemr A, Yasui T, Kitagawa H, Fushida S, Kayahara M, Miwa K, Wakayama T, Iseki S and Yokohama S: Enhanced invasion of pancreatic adenocarcinoma cells stably transfected with cationic trypsinogen cDNA. Int J Cancer 94: 699-704, 2001

33. Uchima Y, Sawada T, Nishihara T, Maeda K, Ohira M and Hirakawa K: Inhibition and mechanism of a protease inhibitor in human pancreatic cancer cells. Pancreas 29: 123-131, 2004.

34. Yoon WH, Jung YJ, Kim TD, Li G, Park BJ, Kim JY, Lee YC, Kim JM, Park JI, Park HD, No ZS, Lim K, Hwang SD and Kim YS: Gabexate mesilate inhibits colon cancer growth, invasion, and metastasis by reducing matrix matalloproteinases and angiogenesis. Clin Cancer Res 10: 4517-4526, 2004.

35. Richardson PG, Barlogie B, Berenson J, Singhal S, Jagannath S, Irwin D, Rajkumar SV, Srkalovic G, Alsina M, Alexanian R, Siegel D, Orlowski RZ, Kuter D, Limentani SA, Lee S, Hideshima T, Esseltine DL, Kauffman M, Adams J, Schenkein DP and Anderson KC: A phase 2 study of bortezomib in relapsed, refractory myeloma. N Engl J Med 348: 2609-2617, 2003

36. Singh S and Aggarwal BB: Activation of transcription NF$\kappa \mathrm{B}$ is suppressed by curcumin (diferuloylmethan). J Biol Chem 270: 24995-25000, 1995. 
37. Dhillon N, Aggarwal BB, Newman RA, Wolff RA, Kunnumakkara AB, Abbruzzese JL, Ng CS, Badmaev V and Kurzrock R: Phase II trial of curcumin in patients with advanced pancreatic cancer. Clin Cancer Res 14: 4491-4499, 2008.

38. Moos PJ, Edes K, Mullally JE and Fitzpatrick FA: Curcumin impairs tumor suppressor p53 function in colon cancer cells. Carcinogenesis 25: 1611-1617, 2004.

39. Holmes-McNary M and Baldwin AS Jr: Chemopreventive properties of trans-resveratrol are associated with inhibition of activation of the IkappaB. Cancer Res 60: 3477-3483, 2000
40. Harikumar KB, Kunnumakkara AB, Sethi G, Diagaradjane P, Anand P, Pandey MK, Gelovani J, Krishnan S, Guha S and Aggarwal BB: Resveratrol, a multitargeted agent, can enhance antitumor activity of gemcitabine in vitro and in orthotopic mouse model of human pancreatic cancer. Int J Cancer 127: 257-268, 2009

41. Athar M, Back JH, Tang X, Kim KH, Kopelovich L, Bickers DR and Kim AL: Resveratrol: a review of preclinical studies for human cancer prevention. Toxicol Appl Pharmacol 224: 274-283, 2007. 